\title{
Growth Curves of Body Weight and Their Relationship to Sexual Maturity in Laboratory-bred Male African Green Monkeys (Cercopithecus aethiops)
}

\author{
Akio HIYAOKA, Takashi YOSHIDA*, Fumiaki CHO*, and Nobuo GOTO** \\ The Corporation for Production and Research of Laboratory Primates, Hachimandai, \\ Tsukuba-shi, Ibaraki 305, *Tsukuba Primate Center for Medical Science, The \\ National Institute of Health, Hachimandai, Tsukuba-shi, Ibaraki 305, and \\ ${ }^{* *}$ Laboratory of Animal Breeding, Faculty of Agriculture, \\ Kobe University, Ncda-ku, Kobe-shi, Hiyogo 657, Japan
}

(Received 14 November 1989/Accepted 4 April 1990)

\begin{abstract}
Nonlinear growth models having a three-or four-parameter family were applied to individual body weight data of 5 male African green monkeys for estimating their growth patterns. Body weight was measured from birth to six years of ageand 58 to 114 data items per monkey were collected. The average body weight atbirth was $360 \mathrm{~g}$ with the standard deviation of $\pm 25 \mathrm{~g}, 4.54 \pm 0.29 \mathrm{~kg}$ at five years of age, and 4.50 $\pm 0.12 \mathrm{~kg}$ at six years of age at which point body weight was judged to have reached a plateau. Five growth models (Gompertz, Logistic, Richards, Bertalanffy and Brody) were applied to the growth data in this study. As a result, two (Gompertz and Logistic) of the five models were found applicable to all data from the five monkeys. However, the coefficient of determination $\left(R^{2}\right)$ obtained by

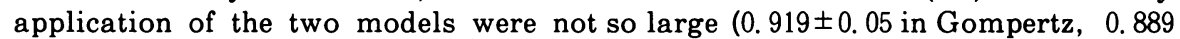
\pm 0.01 in Logistic). Therefore the data were divided into two groups according to monkey age: the first group being from monkeys between birth and 2 years 10 months of age and the second group was from monkeys older than 2 years 10 months of age. The Gompertz model fitted best the data of the first group in four of the five animals $\left(R^{2}=0.982 \pm 0.011\right)$. The age at the inflexion point in the Gompertz model nearly corresponded to the age of weaning. The Logistic model was most suitable for the date of the second group in all five animals $\left(R^{2}=0.955 \pm 0.038\right)$. The age at inflexion point of the Logistic equation corresponded approximately with sexual maturation judged on the bases of changes in skin color of the face and scrotum, changes in testicular size and those in concentration of serum testosterone.
\end{abstract}

オスミドリザルの体重成長の特性と性成熟

冷岡昭雄 ·吉田高志* ·長 文昭* ·後藤信男**

社団法人予防衛生協会

*国立予防衛生研究所筑波医学実験用霊長類センター

***神戸大学農学部家畜育種学教室

我々は, 医学・生物学研究のための実験動物としてサ ル類の人工室内環境下での繁殖を実施している。そのよ
らな条件下で動物の健康を維持・管理するための指標と

して, 体重変化や血液・血清生化学検査値などを用いる 
ことが多い $[17,18]$ 。

ところで，サル類の体重成長に関する報告は，すでに いくつかある $[2,11,13,16]$ が，それらはすべて横断的 調査によるものである。一般に, 動物の成長は個々の動 物を幼龄時より成熟期まで継続的に観察した調査をもと に解析するのが最適である $[7,14]$ 。しかし，このよう な縦断的な調査をおこならことは, 寿命が長く室内飼育 の例が少ないサル類では極めて難しく, わずかにキイロ ヒヒの体重成長を約 8 年間にわたって綎断的に調査した Glassman ら（1984）の報告[6]拉よび彼らの測定值に Logistic 式および Gompertz 式を適用した Shohoji and Sasaki (1985) の報告のみである [15]。筑波医学 実験用霊長類センターではミドリザルについても室内飼 育・繁殖に成功し，一定条件下で動物を長期間観察でき るようになった。そこで，著者らは，メスミドリザルの 体重の個成長に, 成長モデル式である Gompertz 式を 適用して詳細に解析し, 成長の変曲点時期は䊒の性成熟 と密接な関係があることを認めた $[8]$ 。今回は, オスミ ドリザルの体重成長に最も良く適合する成長モデル式 $[5,12]$ にいて検討した。さらに, 得られた式のパラ メーターから算出される変曲点の位置と, 動物の離乳 （母仔分離）時期および性成熟期の指標である性皮の色 調変化や精巣の大ささの変化および血中テストステロン 濃度との関係について検討した。

\section{材料と方法}

動物は，筑波医学実験用霊長類センターで出生したオ スミドリザル (Cercopithecus aethiops) 5 頭である。 飼育環境は，当センターで大規模な繁殖を実施している カニクイザルとお打むね同様である[9]。すなわち，動 物は朝 5 時点灯, 夜 7 時消灯の 1 日14時間照明, 温度は $25 \pm 2{ }^{\circ} \mathrm{C}$ ，湿度は60土10\%，換気回数は12回/時に設定 された室内で飼育した。飼料は，1頭あたり午前にリン ゴ, ミカンを各 $100 \mathrm{~g}$, 午後に, オリェンタル社製サル 用固型飼料 AS 型を $70 \mathrm{~g}$ 給餌した。出生後, 約 15 週齢ま では実母による哺育を抏こない離乳後から約 1 歳齢まで は，ほぼ同年龄の 2 頭を個別ケージ（高さ $60 \mathrm{~cm} \times$ 横 40 $\mathrm{cm} \times$ 奥行き $60 \mathrm{~cm}$ ）で同居飼育した。その後は，個別ヶ ージ $2 \sim 3$ 台からなる連結ヶージで, $2 \sim 6$ 頭の群飼育 を実施した。約 4 歳龄からは 1 ケージ 1 頭で飼育した。

体重測定及び解析 : 体重は, 午前 9 時30分から11時の 間で，かつ給慨前に測定し，原則として生まれてから離 乳するまでは週に 1 回, 離乳後は週に 1 ないし 2 回, 1 歳龄以上は月 1 回測定し, 計 1 頭あたり58から 114 回,
6 歳齢まで実施した。その測定值に各個体毎に 5 種類の 成長モデル式 (Logistic, Gompertz, Bertalanffy, Richards, Brody の式)の適用を試みた $[5,12]$ 。実測 値とモデル式との適合の程度は, 決定係数の值 $\left(\mathrm{R}^{2}\right)$ お よびモデル式から得られた体重の推定値と実測値との差 で検討した。

性成熟期調査 : 性皮の色調変化は, 毎日の外観観察に より判定した。精巣の大きさは，陰のら上からノギスを 用いて長径, 短径および幅を外部から測定し相対容積を 算出した $[10]$ 。また, 体重 $1 \mathrm{~kg}$ あたり $0.1 \mathrm{ml}$ の塩酸ヶ タミン（ケタラール 50 , 三共）の筋肉内投与による麻酔 下において, 午前10時から11時の間に大腿部内側静脈か ら，採血も扎こなった。採血は，5頭の動物で延べ25回 おこなった。育成個体の血中テストステロン濃度と比較 する為に, 当センターですでに繁殖活動を行っている野 生由来成獣オス14頭からす採血をおこなった。採血後,

$4{ }^{\circ} \mathrm{C}, 3,000 \mathrm{rpm}$ 15分の遠心分離により,すみやかに 血清を得た。血清はホルモン測定までー $20{ }^{\circ} \mathrm{C}$ に保存し た。血中テストステロン量の測定は, ラジオイムノアッ セイ（テストステロン“栄研”, 栄研イムノケミカル研 究所）によった。

\section{成 繶}

1. 体重変化

5 頭の被検ザルの体重変化を Fig. 1 に示す。これら

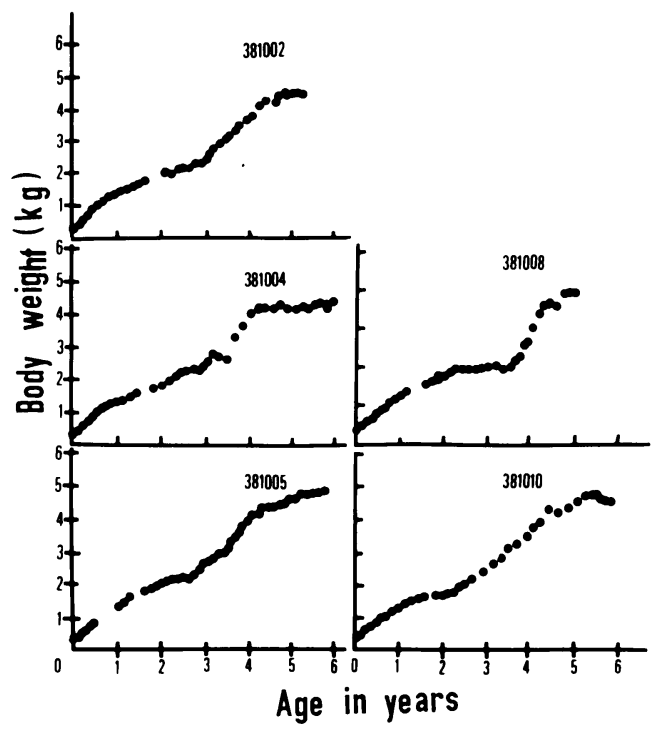

Fig. 1. Changes of body weight with age in five laboratory-bred male African green monkeys 
Table 1. Nonlinear growth models with three-or four-parameters applied in the study

\begin{tabular}{|c|c|c|c|c|}
\hline Model & Equation (Yt) & $\begin{array}{l}\text { Mature } \\
\text { size }\end{array}$ & $\begin{array}{c}\text { Rate of } \\
\text { maturation }\end{array}$ & $\begin{array}{l}\text { Inflexion } \\
\text { point }\end{array}$ \\
\hline & & & & $\left(\mathrm{Y}^{*}, \mathrm{t}^{*}\right)$ \\
\hline Gompertz & $\mathrm{Yt}=\mathrm{Ae}^{-\mathrm{Be}-\mathrm{Kt}}$ & A & $\mathrm{K}$ & $\mathrm{e}^{-1} \cdot \mathrm{A}, \frac{\ln \mathrm{B}}{\mathrm{K}}$ \\
\hline Brody & $\mathrm{Yt}=\mathrm{A}\left(1.0-\mathrm{Be}^{-\mathrm{Kt}}\right)$ & A & $\mathrm{K}$ &,$- \quad-$ \\
\hline Logistic & $\mathrm{Yt}=\mathrm{A}\left(1.0+\mathrm{Be}^{-\mathrm{Kt}}\right)^{-1}$ & A & $\mathrm{K}$ & $1 / 2 \cdot A, \frac{\ln B}{K}$ \\
\hline Bertalanffy & $\mathrm{Yt}=\mathrm{A}\left(1.0-\mathrm{Be}^{-\mathrm{Kt}}\right)^{3}$ & A & $\mathrm{K}$ & $8 / 27 \cdot A, \frac{\ln 3 B}{K}$ \\
\hline Richards & $\mathrm{Yt}=\mathrm{A}\left(1.0-\mathrm{Be}^{-\mathrm{Kt}}\right)^{1 /(1-\mathrm{m})}$ & A & $\mathrm{K}$ & $\mathrm{m}^{1 /(1-\mathrm{m})} \cdot \mathrm{A}, \frac{\ln (\mathrm{B} / 1-\mathrm{m})}{\mathrm{K}}$ \\
\hline
\end{tabular}

$\mathrm{Y}^{*}, \mathrm{t}^{*}: \mathrm{Y}$ value at time of inflexion point $\mathrm{t}^{*}$

Table 2. Coefficient of determination obtained by applying each growth model to body weight data from monkeys between birth and 2 years and 10 months of age

\begin{tabular}{ccccccc}
\hline \multirow{2}{*}{$\begin{array}{c}\text { Animal } \\
\text { No. }\end{array}$} & Measurement & Gompertz & Brody & Logistic & Bertalanffy & Richards \\
\cline { 3 - 6 } & 77 & 0.977 & 0.303 & 0.267 & - & - \\
381002 & 83 & $-{ }^{*}$ & - & 0.957 & - & - \\
381004 & 76 & 0.989 & - & - & - & - \\
381005 & 34 & 0.993 & - & 0.906 & - & - \\
381008 & 67 & 0.969 & - & 0.944 & - & - \\
381010 & 76 & & & &
\end{tabular}

$*$ : Not applicable

Table 3. Body weight and age at inflexion point obtained by Gompertz model and body weight and age at weaning in each monkey

\begin{tabular}{cccccc}
\hline \multirow{2}{*}{$\begin{array}{c}\text { Animal } \\
\text { No. }\end{array}$} & \multicolumn{2}{c}{ At inflexion point } & & \multicolumn{2}{c}{ At weaning } \\
\cline { 2 - 3 } \cline { 5 - 6 } & Body weight $(\mathrm{g})$ & Age (months) & & Body weight (g) & Age (months) \\
\hline 381002 & 670 & 2.7 & & 730 & 3.3 \\
381004 & $-{ }^{*}$ & - & & 730 & 3.3 \\
381005 & 796 & 4.2 & & 700 & 3.3 \\
381008 & 846 & 5.2 & & 660 & 3.3 \\
381010 & 748 & 4.9 & & 670 & 3.8 \\
\hline
\end{tabular}

*: Not applicable

5 頭の体重の平均値と標準偏差は, 出生時には $360 \pm 25$

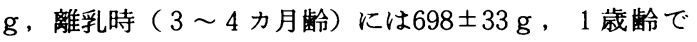
は $1.55 \pm 0.8 \mathrm{~kg}$ であった。2 歳 3 カ月齢頃から体重増 加率は, それ以前と比べ減少した。しかし，2歳10力月
齢を越えるころから再び急激な増加率を示すようになっ た。 4 歳齢では $4.40 \pm 0.23 \mathrm{~kg}, 5$ 歳齢では $4.54 \pm 0.29$ $\mathrm{kg}, 6$ 歳龄では $4.50 \pm 0.12 \mathrm{~kg}$ であり， 5 歳齢頃にほぼ 一定の值を保つょうになった。 
Table 4. Coefficient of determination obtained by applying each growth model to body weight date from monkeys between 2 years and 10 months and 6 years of age

\begin{tabular}{ccccccc}
\hline \multirow{2}{*}{$\begin{array}{c}\text { Animal } \\
\text { No. }\end{array}$} & Measurement & Gompertz & Brody & Logistic & Bertalanffy & Richards \\
\cline { 2 - 7 } 381002 & 27 & 0.974 & 0.969 & 0.978 & 0.973 & $-*$ \\
381004 & 31 & 0.881 & 0.871 & 0.890 & 0.878 & - \\
381005 & 31 & 0.975 & 0.970 & 0.978 & 0.974 & - \\
381008 & 24 & 0.993 & 0.992 & 0.952 & 0.994 & - \\
381010 & 33 & 0.976 & 0.971 & 0.979 & 0.974 & - \\
\hline
\end{tabular}

$*$ : Not applicable

Table 5. Mature size, body weight and age at inflexion point obtained by Logistic model in each monkey

\begin{tabular}{cccc}
\hline $\begin{array}{c}\text { Animal } \\
\text { No. }\end{array}$ & $\begin{array}{c}\text { Mature } \\
\text { size }(\mathrm{kg})\end{array}$ & $\begin{array}{c}\text { Body weight }(\mathrm{kg}) \\
\text { at inflexion point }\end{array}$ & $\begin{array}{c}\text { Age in years at } \\
\text { inflexion point }\end{array}$ \\
\hline 381002 & 4.62 & 3.91 & 4.2 \\
381004 & 4.53 & 3.28 & 3.5 \\
381005 & 5.13 & 3.71 & 3.7 \\
381008 & 5.66 & 4.13 & 4.4 \\
381010 & 4.86 & 3.35 & 3.5 \\
\hline
\end{tabular}

\section{2. 成長モデル式の適用}

オスミドリザルの体重の実測値に成長モデル式を当て はめてその適合性を検討した。今回適用した成長モデル 式をTable 1 に示した。さらに，それぞれの式のパラ メーター,すなわら成熟値, 成長速度およびこれらから 算出される変曲点の位置 ( $\mathrm{Y}$ 座標, $\mathrm{t}$ 座標) も示した。 $2-1$. 全測定期間

体重の全測定期間を通して適合した成長モデル式は, Gompertz 式（以下 $G$ 式） $\left(R^{2}=0.919 \pm 0.05\right)$ と Logistic 式（以下L式） $\left(R^{2}=0.899 \pm 0.08\right)$ であっ た。しかし, 決定俰数が最も大であった $\mathrm{G}$ 式から求めた 体重の推定値と実測値との差は, 対実測値の最大 $40 \%$ に 及ぶ場合もあった。そこで体重増加率が減少を示し, 測 定値が一時的に一定となり, 再び急激な体重増加をはじ める直前の時期である 2 歳10力月龄で測定值を 2 期に分 割し、それぞれに成長モデル式を適合させることを試み た。

\section{2-2. 出生から 2 歳10力月龄まで}

出生から2 歳10カ月龄までの体重成長に適合した式 は， 5 頭中 4 頭でG式とL式であった。しかし，それ ぞれ 1 頭ずつ適合しない個体があった。両式で適合しな
かった個体は，異なっていた。G式に適合した 4 個体 の決定係数 $(0.982 \pm 0.011)$ は，L式より大きかった (Table 2)。

$\mathrm{G}$ 式のパラメーターから算出される変曲点の位置とオ スミドリザルの離乳時期との関係を Table 3 に示した。 $\mathrm{G}$ 式の変曲点の位置は, 体重では670 846 $\mathrm{g}$ のとで, 年龄では生後2.7 5.2 月月龄のころであった。 5 頭の離

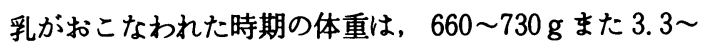
3.8カ月龄であった。

\section{2-3，2 歳10カ月龄から6 歳齢まで}

2 歳10カ月齢から 6 歳齢までの体重成長に適合した成 長モデル式は，Richardsを除く全ての式であった。 それぞれの式より得られた決定俰数を個体毎に見てみる と 1 頭を除いてL式が最す高い值であった。1頭（動物 番号381008）は，Bertalanffy 式を適合させたときに 決定係数が最も大きい值であった（Table 4)。

L 式のパラメーターである成熟值および変曲点の位直 をTable 5 に示した。L式の変曲点の位置は, 体重で は3. $28 \sim 4.13 \mathrm{~kg}$ のときで, 年龄は 3 歳 5 カ月龄〜 4 歳 4 カ月龄であった。 


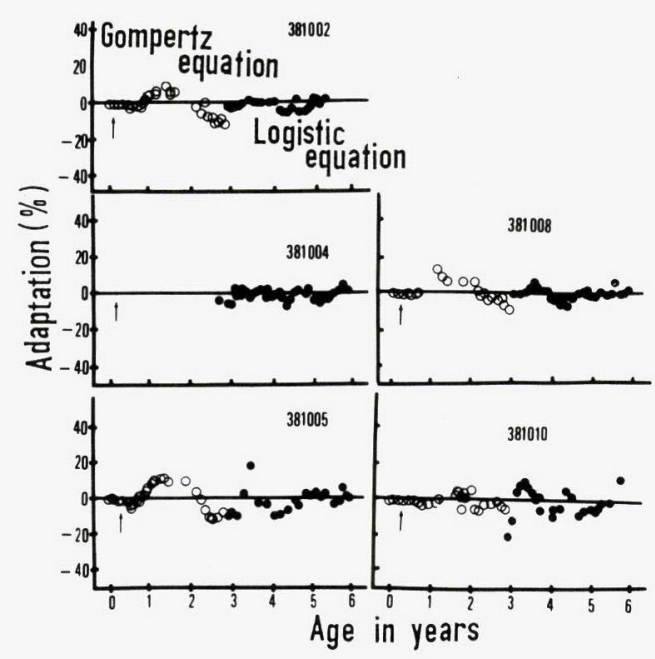

Fig. 2. Application of body weight data from laboratory-bred male African green monkeys to Gompertz and Logistic models. Gompertz model was adapted for body weight data $(O)$ from monkeys between birth and 2 years and 10 months of age except Animal No. 381004, and Logistic model was adapted for data from those ( between 2 years and 10 months of age and the end of observation period. Adaptation (\%) was calculated using $\frac{(a-b)}{a}$ $\times 100$ a : actual body weight $\mathrm{b}:$ body weight calculated from each equation adapted Arrow indicates time of separation from mother monkev
3. 成長モデル式からの推定値と実測値との適合度

2 歳10カ月齢までの体重に $\mathrm{G}$ 曲線を, また, それ以降 の体重にL曲線を適合させたときの推定値と実際の測定 値との適合度をFig. 2 に示した。両者の差と実測值と の比率 (パーセント) 〔100 × (実測值一推定値)/実測值 は，最大約20\%以内の範囲内におさまった。いずれの個 体でも 1 ～歳秢ごろに低めに推定された以外は, 推定 值と実測値はほぼ一致した。

4. 性成熟調查

$4-1$. 性皮の色調

2 歳 6 カ月齢と 4 歳齢のオスミドリザルの全身をFig. 3 亿示した。2 歳 6 カ月秢の顔面は, 肌色で眼のまわり のみやや黒色を呈し, 陰のらは肌色であった。4 歳齢に なると顔面は全体的に一段と黒くなり，陰のうは鮮やか な青色になった。

\section{$4-2$. 精巣の大きさ}

1 歳齢から 2 歳 6 力月齢までの精巣の相対体積は, 7 以下であった。 3 歳秢をすぎた頃から急激に増加し， 4 歳齢では, 25〜30 と約 4 倍にまで大きくなった（Fig. 4 )。

4-3. テストステロン濃度

血中テストステロン濃度を Fig. 5 と示した。1 歳跉 から 3 歳 6 カ月齢までは, $3 \mathrm{ng} / \mathrm{ml}$ 以下の低值であっ た。 3 歳 6 カ月齢をすぎてから $12 \sim 25 \mathrm{ng} / \mathrm{ml}$ と増加し, 野生由来成熟オスミドリザルとほぼ同じ值を示した。
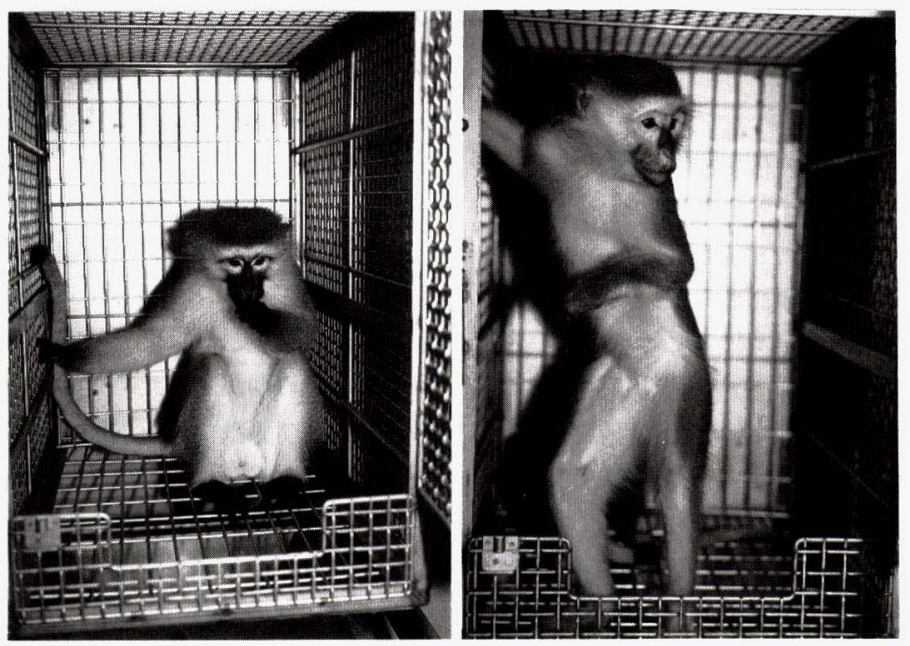

Fig. 3. Pre-pubertal male (left) and fully mature male (right) African green monkeys. Note the differences in skin color of theface and scrotum. 


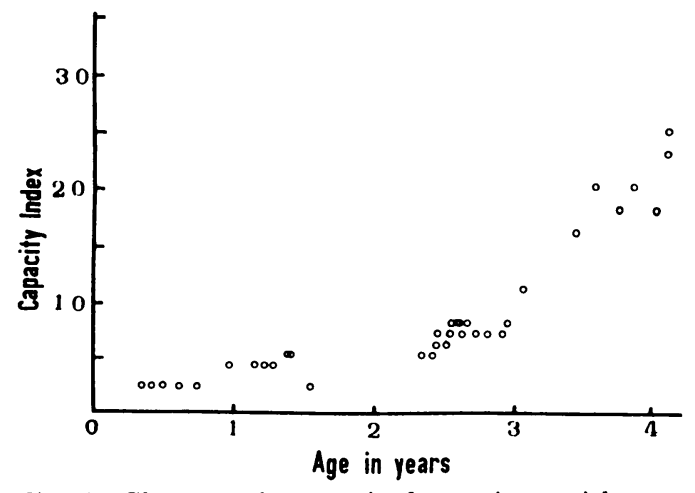

Fig. 4. Change in testicular size with age. Capacity index was calculated using $(\mathrm{a} \times \mathrm{b} \times$ c). a : major axial length in $\mathrm{cm} \quad b$ : minor axial length in $\mathrm{cm} \quad \mathrm{c}:$ width in $\mathrm{cm}$

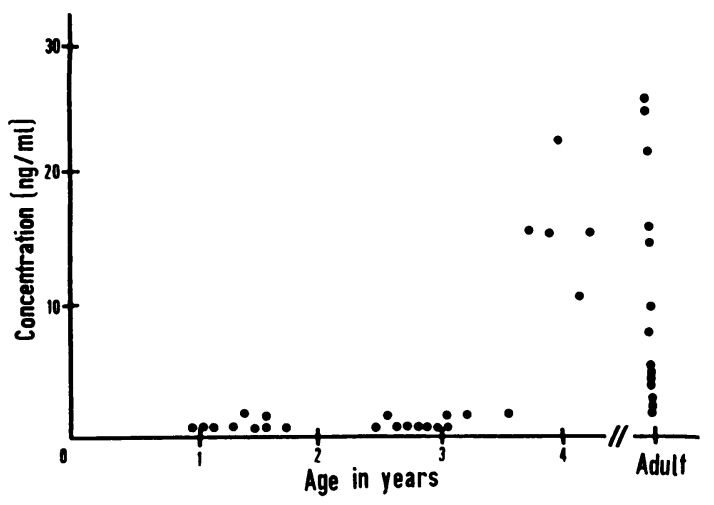

Fig. 5. Changes in serum testosterone concentration with age and concentration in originally wild adult monkeys

\section{考察}

本研究では, オスミドリザルの体重成長の解析をおこ なら目的で 5 頭の育成個体の体重を継続的に測定した。 これらの測定値を解析する目的で 5 種類の成長モデル式 の適用を試みた [7]。併せて, 顔面および性皮の色調, 精巣の大きさ, 血清テストステロン濃度について観察ま たは測定を実施し，体重成長と性成熟との関係について 検討した。

オスミドリザルの体重成長には, 乳・幼仔期と 3 歳龄 頃との 2 回にわたり体重増加率が急増寸る時期（成長促 進期）のあることが判明した。乳幼仔期の成長促進期 は，実母による哺育期間に相当し，それは仔ザルが実母 から十分に栄養を得ていることの反映であると推定され る。その後, 離乳時期を境に 2 歳龄頃までは, 比較的緩 やかな体重成長を示し，2歳龄をすぎたころ体重成長

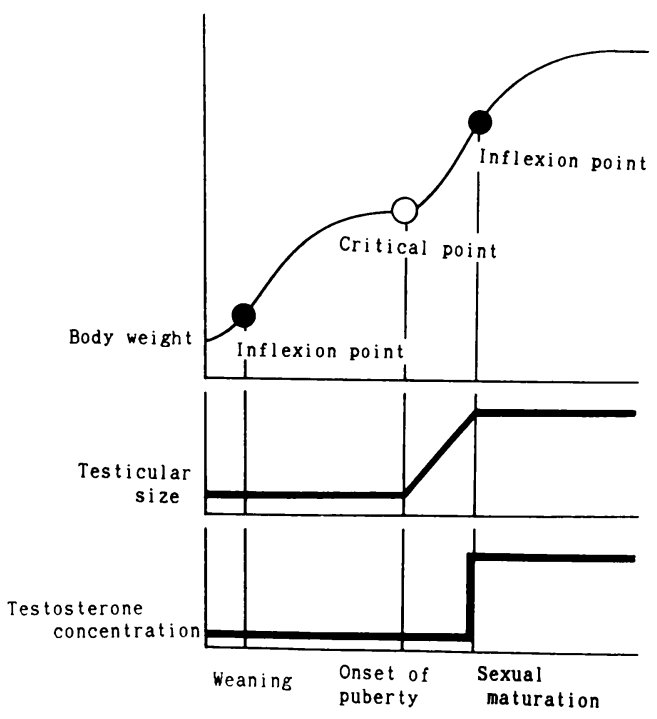

Fig. 6. Scheme of growth pattern in laboratorybred male African green monkeys

は、ほとんど停滞した。そして，2 歳10力月龄から再び 急激な体重の増加を示し，5歳齢以降から安定した測定 値を示した。

一方, メスミドリザルの体重は, オスミドリザルのよ 5に一時的に成長が停滞することがなく, 出生から 2 歳 6 力月龄ごろまで増加して 4 歳龄で一定の值を示した。 この体重成長に適合した成長モデル式は, 全測定期間を 通してG式 $\left(\mathrm{R}^{2}=0.958 \sim 0.991\right)$ であった[8]。メスミ ドリザルにおいて性成熟にとすなら成長促進期が存在せ ずオスミドリザルにおいてのみそれが存在した理由に ついは, 現在のところ不明であり今後の検討課題であ る。オスミドリザルの場合は， G 式と L 式が全測定期間 を通してほぼ啇合した。しかし，この2式より得られた 実測値と推定値との間には, 対実測値にして最大 $40 \%$ む の差が認められ, 得られた決定係数の值もメスに比べて 低かった（G式0.919，L式0.899）。それは，オスの場 合， 2 歳齡を過ぎた頃に一時的に体重増加がほとんど認 められない時期があるためと考えられる。そこで体重測 定値を, 再び急激な体重増加を示すようになる2歳10力 月龄を境に，それ以前と以降の 2 期に分けて検討を加え ることにした。

出生から 2 歳10カ月龆までの体重成長に適合したモデ ル式は， 5 頭中 4 頭で $\mathrm{G}$ 式と L式の 2 式であった。決定 係数の值から, 乳幼時期は $G$ 式が最も良く適合したも のと判断した。G式に適合しなかった 1 頭（動物番号 381004）は, 同居中他個体より攻撃され負傷した経歴が 
あり，一時的に体重の減少が認められたサルであった。 $\mathrm{G}$ 式に適合した個体では, 得られた変曲点の位置は 3 5 カ月龄にあり,この頃おこなわれる仔ザルの離乳の時 期にほぼ一致した。我々は, 出生後約 3 力月以上を経て 仔ザルがしばしば母ザルから離れ, 自分で固型飼料等も 食べるよらになること, 乳歯が第 1 小四歯まで萌出して いること, および体重が $650 \mathrm{~g}$ 以上になっていること等 を基準にして離乳させている。このように人為的になさ れる離乳の時期と, 仔ザルの体重成長の変曲点の存在す る時期とが一致することは, 興味深い現象である。この ことが当センターの飼育方法にともなら固有の現象であ るのか, あるいはミドリザル特有のことなのか, 今後, 飼育方法等とともに詳細に解析したい。ところでG式よ り求めた推定値と実測値との差は，0日齢から１歳齢ま ではほとんど差がなかった。このことは母ザルによる哺 育が順調におこなわれて，発育良好であることを意味し ていると判断される。さらに離乳後も実測値は推定值と ほぼ一致したことは, この期間も順調な体重増加を呈し ていることを意味している。次に，1２歳龄までは， 実測值は推定値をらわまわった。このことは,この時期 の体重増加率が期待される以上に大きかったことを意味 している。この頃は, 通常 $2 \sim 6$ 頭の群飼育の時期であ り, 同居個体とともに順調に成長しているものと判断さ れる。全体的には両者の差は実測値の約20\%以内であり 概ね適合していると判断した $[8]$ 。

2 歳10カ月龄から 6 歳までの体重成長に適合したモデ ル式は，5頭とも Richardsを除いた 4 式である。決 定係数の值が最も大であったのは，5頭中 4 頭ではL 式 であった。残り 1 頭については, Bertalanffy 式が最も 良く適合した。1頭だけが Bertalanffy 式に良く適合 した理由は明かでない。Bertalanffy 式を適合させた場 合, $\mathrm{G}$ 式と L 式に比べて変曲点の位置が, すこし早期に 推定される。いずれにせよ決定係数の值から L式は, 成 熟期の体重成長に充分に適合していると判断した。L式 のパラメーターから算出された変曲点の位置は 4 歳路頃 であった。また，L式から得られた実測值と推定值との 差は, 実測値の最大約 $20 \%$ 以内であったことから，L式 は 2 歳10カ月龄以降のオスミドリザルの体重成長と良く 適合していると判断した $[8]$ 。

ニホンザル，カニクイザル等の性成熟期は，4歳から 5 歳龄にありこの頃は性皮の色調も変化する $[4,10]$ 。 また，体重増加の促進期から非增加期に移行する時期 は, 性成熟の完了時期に対応するとされており, 体重の 成長速度が, 性ホルモンの分泌と関係が深いといら報告 と合致していた $[1,3]$ 。本報で記したように, 当センタ
一のオスミドリザルにおいても，3 歳から 4 歳龄にかけ て陰のうや顔面の色調が大きく変化した。精巣の大きさ も2 歳 6 力月龄頃から大きくなり始め 4 歳龄でほぼ成熟 野生由来雄ミドリザルと同じ大きさとなった。また，血 中テストステロン濃度も $2 \sim 3$ 歳齢は低値であったが 4 藏龄頃には成熟野生由来雄ミドリザルとほぼ同じ值にな つた。本来ならば体重成長と性皮の色調の変化や精巣の 大きさ，血中ホルモン濃度などの関係は個体毎に対応さ せて論ずべきではあるが，例数も少なくまた測定回数も 少ないために, 平均的にこれらの関係について考察する ことにした。

ミドリザルでは 2 歳10カ月齢ごろから性成熟が開始さ れるようになり，4歳齢ごろにはそれが完了するものと 判断される。 2 歳10力月龊以前の数力月間の体重成長の 停滞は,このような性成熟開始のための準備期間である ことと対応しているものと判断される。他方，2歳10力 月龄を境に, 体重が急激に増加することは, 性成熟の開 始にともなら体重成長の促進現象を示し, 変曲点以降の 体重の増加率の减少は, 性成熟の完了にともなら体重成 長の抑制現象を示しているようである。このことを模式 的に表したものが Fig. 6である。

我々は長期間にわたりミドリザルの体重測定を実施 し, 人工的飼育環境下での, ミドリザルの体重成長特性 について明らかにすることができたと考えている。

\section{要 約}

筑波医学実験用霊長類センターにて繁殖・育成した 5 頭のオスミドリザルの体重を出生から 6 歳龄まで継続的 に測定した。体重の平均値と標準偏差は, 出生時は 360 $\pm 25 \mathrm{~g}$ であった。1 歳龄は $1.55 \pm 0.8 \mathrm{~kg}, 2$ 歳龄は2.50 $\pm 0.12 \mathrm{~kg}$ で, 2 歳 3 力月龄頃から体重の増加率は以前 と比べて减少した。そして，3歳龄頃から再び急激な 体重増加を示した。 4 歳龄は $4.40 \pm 0.23 \mathrm{~kg}, 5$ 歳齡は $4.54 \pm 0.29 \mathrm{~kg}, 6$ 歳齢は $4.50 \pm 0.12 \mathrm{~kg}$ と約 5 歳龄でそ れ以後とほぼ同じ値に達した。オスミドリザルの体重を 5 つの成長モデル式に当てはめた結果, 全測定期間を通 してオスミドリザルの体重に適合した式は, Gompertz 式とLogistic 式であった。決定係数 $\left(\mathrm{R}^{2}\right)$ の值から, 最もよく適合したモデル式は Gompertz 式であった。 しかし, 成長モデル式より求めた体重推定值と実測値の 差は, 対実測值にして最大 $40 \%$ 場合もあった。また,

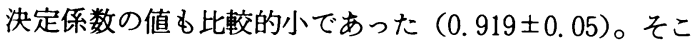
で, 測定値を急激に体重増加を示す 2 歳 10 力月齢以前 と以降の 2 群に分割し，それぞれに成長モデル式を適 
合させた。出生から2歳10カ月齢までは Gompertz 式 $\left(\mathrm{R}^{2}=0.982 \pm 0.011\right)$ が, それ以降は Logistic 式が最 も良く適合した $\left(\mathrm{R}^{2}=0.955 \pm 0.038\right)$ 。Gompertz 式の パラメーターから推定される変曲点の位置は, 仔ザルの 離乳時期に対応した。Logistic 式における変曲点の時 期は，性成熟の指標である性皮の色調変化や精巣の大き さおよび血中テストステロン浱度の変化と関係が認めら れた。

稿を終えるに臨み，終始有益な御助言と奖励をいたたいた国 立予研・筑波藼長類センター前所長本庄重男博士に深謝いたし 立す。なお，本研究にあたってデータ解析に農林水産省研究計

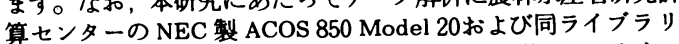
一を使用させていただきました。つつしんで感謝いたします。

\section{文 嶰}

[1] Arslan, M., Mahmood, S., Naqvi, M. A., and Baig, S. M. (1986). Changes in circulating levels of immunoreactive follicle stimulating hormone, luteinizing hormone, and testosterone during sexual development in the rhesus monkey, macaca mulatta. J. Med Primatol, 15, 351-359.

[2] Chapman, C. A. (1987). Selection of secondary growth areas by vervet monkeys. (Cercopithecus aethiops). Am J. Primatol, 12, 217-221.

[3] Carlisle, K. S., Brenner, R. M., and Montagna, M. (1981). Hormonal regulation of sex skin in macaca nemestrina. Biol Reprod, 25, 1053-1063.

[4] Cho, F., Fujiwara, T., Honjo, S., and Imaizumi, K. (1973). Sexual maturation of laboratory-bred male cynomologus monkeys (Macaca fascicularis). Exp. Anim, 22, 403-409.

[5] Eisen, E. J., Lang, B. J., and Legates, J. E. (1977). Comparison of growth functions within and between lines of mice selected for large and small body weight. The or. Appl Genet., 39, 251-260.

[6] Glassman, D. M., Coelho, A. M., Carey, K. D., and
Bramblett, C. A. (1984). Weight growth in savannah baboons : A longitudinal study from birth to adulthood. Growth 48, 425-433.

［7] 後藤信男（1987）. 成長のとらえ方. 動物の成長と発育, pp. 34-53. 猪 貴義・後藤信男・星野忠彦・佐藤 博 編, 朝倉書店, 東京.

［8］椧岡昭婎・吉田高志・長 文昭・後藤信男(1989). メス ミドリザルの個成長の解析一性成熟と体重との関係一実 耠動物, 38, 239-244

[9] Honjo, S. (1985). The Japanese Tsukuba Primate Center for Medical Science (TPC) : An outline. J. Med Primatol, 14, 75-89.

[10］和 秀雄. (1982). ニホンザル 性の生理. 和 秀雄編, 自然誌選書, 東京.

［11］大藤浩美・鈴木通弘・大久保文雄・鴻野 操・清水利行 -成田勇人・羽成光二・小松畸克彦・小野考浩・吉田 高志・長 文昭(1987). 大規模システムでのカニクイザ ルの体重成長. 成長, 25，195-197.

[12] Richards, F. J. (1983). A flexible growth function for empirical use. J. Exp. Bot., 10, 290-300.

[13] Rutenberg, G. W., Anthony, M. C., JR., Douglass, S. L., Carry, K. D., and Henry, C., Mcgill, JR. (1987). Body composition in baboons (Papio cynocephalus anubis) : Evaluating a morphometric method. Amer. J. Primatol, 12, 275-285.

[14] 清水三雄(1957). 動物の成長. pp. 14-17. 北隆館, 東 京.

[15] Shohoji, T. and Sasaki, H (1985). An aspect of growth analysis of weight in savannah baboon. Growth, 49, 500-509.

[16] Van Wagenen, G. and Catchpole, H. R. (1956). Physical growth of the rhesus monkey. (Macaca mulatta). Am $J$ Reprod 14, 246-273.

[17] Yoshida, T. (1981). The Changes of hematological and biochemical properties in cynomolgus monkeys (Macaca fascicularis) after importation Japan J. Med Sci Biol, 34, 239-242.

[18］吉田高志・後藤幸江・羽成光二・清水利行・中島雅子・ 長 文昭・本庄重男 (1982)。乳仔期カニクイザル (Macaca fascicularis) の個成長の管理. 成長, 21 , 12-19. 